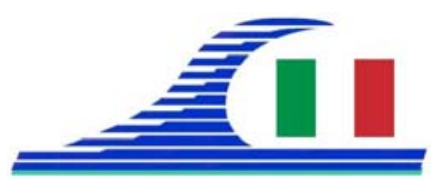

\author{
Conférence Méditerranéenne Côtière et Maritime \\ EDITION 3, FERRARA, ITALIA (2015) \\ Coastal and Maritime Mediterranean Conference \\ Disponible en ligne - http://www.paralia.fr - Available online
}

\title{
Sediment budget and management of the Veneto beaches, Italy: an application of the modified Littoral Cells Management System (SICELL)
}

\author{
Giorgio FONTOLAN ${ }^{1}$, Annelore BEZZI ${ }^{1}$, Davide MARTINUCCI ${ }^{1}$, \\ Simone PILLON ${ }^{1}$, Chiara POPESSO ${ }^{1}$, Federica RIZZETTO ${ }^{2}$
}

1. Università degli Studi di Trieste, Dipartimento di Matematica e Geoscienze, Via E.Weiss, 1, 34128 Trieste, Italy.

fontolan@units.it

2. CNR-ISMAR, Istituto di Scienze Marine,

Arsenale, Tesa 104, Castello 2737/F, 30122 Venezia, Italy.

federica.rizzetto@ve.ismar.cnr.it

\begin{abstract}
:
A practical tool for coastal data spatial cataloguing based on sediment budget computation is herein proposed and discussed, using a modified version of the Littoral Cells Management System (SICELL) originally created by the Emilia-Romagna Region, Italy. For coastal management purposes, a geodatabase of the Veneto coast has been constructed, that includes 77 sedimentary units or cells, described by physicalmorphological, evolutionary, land-use pressure and coastal defences data. Each littoral cell is basically identified by the more recent pluriannual sediment budget state, i.e. Accretionary, Stable, Precarious and Erosional (ASPE). The modified version of SICELL includes the sediment budget computation and equilibrium state of 5 river mouths and 5 ebb-tidal deltas cells, considered as specific nearshore sedimentary sinks. There, sand stored or dredged for navigation could be used to nourish adjacent erosional beach cells, respecting their natural morphodynamic relationship.
\end{abstract}

Keywords: Coastal database, Sediment budget, Coastal management, Geographic Information System (GIS), Tidal inlets, Beach nourishment.

\section{Introduction}

Whichever Decision Support System applied to coastal problems (episodic inundation or long-term risks) is based on a geodatabase within a GIS. According to KAMINSKY \& GENFELBAUM (2000) tools adopted have two priorities: i) predict coastal behaviour at scales relevant to management, ii) provide technical assistance that directly link scientific research with coastal management needs.

A practical approach for data cataloguing and elaboration based on sediment budget computation is given by the Littoral Cells Management System (SICELL) proposed by the Emilia-Romagna Region, Italy (REGIONE EMILIA-ROMAGNA, 2011). Coastal area is divided in cells or compartments, according to the sediment budget 
Côtes méditerranéennes menacées :

Risques et défis dans le contexte du changement climatique

characteristics, in order to evaluate their Accretionary, Stable, Precarious and Erosional (ASPE) state, and thus to establish criteria for possible solution of deficit areas.

A geodatabase is created using a GIS software, which gives the possibility to store, georeference and compare data, analyze spatial information and create maps. It represents an important tool for the immediate interpretation of the beach system dynamics and for coastal planning, also in view of future climate changes and sea-level rise. Consequently, it provides fundamental support for artificial beach nourishment, coastal protection, urban organization, environmental restoration and habitat protection. In this paper we propose and present an application of a modified version of the SICELL, which includes a supplementary classification of the potential sedimentary sources and sinks, as river mouths and tidal inlets, in the perspective of re-using the sediments within adjacent cells when dredging or maintenances for navigation are needed.

\section{Materials and methods}

The study was carried out on the littoral of Veneto, north Adriatic Sea, Italy. Coastline consists of sandy beaches, strongly affected by tourism, exceeding 12 million presences during the Summer season. From the geomorphological point of view, the littoral can be divided in several physiographic units or large compartments, whose limits are represented by shoreline interruptions due to the presence of river mouths or tidal inlets. Coastal data, mainly provided by the Veneto Region, were organized into a geodatabase (GCV) containing information about the physical characteristics, the coastal evolution and the human activities that affected the geomorphological modifications of the littoral and influenced local management. The monitoring data consisted mainly of cross shore profiles, various orthophoto datasets and a 2013 LIDAR dataset. The 337 cross shore topo-bathymetric profiles, surveyed between 1968 and 2010 with varying update rates, are not evenly distributed along the coast: 314 are distributed along $62 \mathrm{~km}$ of coast while only 23 describe the remaining $30 \mathrm{~km}$. In the GCV, spatial and alphanumeric data were organized in order to represent the three main key groups of variables for coastal morphologies and processes: (1) beach state and connection with the hinterland (beach width, shoreface, sedimentology, impact of tourism, land-use pressure); (2) evolutionary dynamics (shoreline evolution, beach and upper shoreface sediment budget, artificial beach nourishment); (3) coastal defences (hard and soft protections and coastal dunes). Moreover, data were structured to allow analysis at the level of detail (single geographic entity) and at the level of sedimentary cells (territorial units characterized by homogeneous erosional/depositional style).

\section{Results}

The entire $98.7 \mathrm{~km}$ of the studied area were divided in 77 sedimentary units or cells, as follows: $92 \mathrm{~km}$ were divided in 65 littoral cells (from $158 \mathrm{~m}$ to $3712 \mathrm{~m}$ long); $6 \mathrm{~km}$ 
were classified in 10 cells as river mouth (5) and tidal inlets (5); $0.7 \mathrm{~km}$ (2 cells) represent ports and harbours.

The 65 littoral cells were classified on the basis of the average values of the most recent pluriannual (between 2001-2010, 2003-2010, 2002-2007, according to the available dataset) sediment budget. Subdivision of the coast into discrete territorial units follows the "homogeneous evolutionary style" criterion, i.e. erosion, accretion and stability, referred to both the beach and the upper shoreface. Due to highly variable data density (see chapter 2) it was not possible to achieve homogeneous cell spacing. Four main classes may be identified (ASPE code): 1) A (Accretion), sedimentary accumulation greater than $5 \mathrm{~m}^{3} / \mathrm{m}$ per year; 2) $\mathrm{S}$ (Stable), sedimentary rate between -5 and $+5 \mathrm{~m}^{3} / \mathrm{m}$ per year; 3) P (Precarious), sedimentary rate between -5 and $+5 \mathrm{~m}^{3} / \mathrm{m}$ per year but only where the budget has been altered by beach nourishment with a significant amount of sand; 4) E (Erosion), erosion rate greater than $5 \mathrm{~m}^{3} / \mathrm{m}$ per year. The group "E" has been further detailed according to the rate of erosion (moderate $\mathrm{E} 1=5-20 \mathrm{~m}^{3} / \mathrm{m}$ per year; strong E2 $>20 \mathrm{~m}^{3} / \mathrm{m}$ per year) and, in relation to the same rate of erosion, modification of sediment budget due to beach nourishment has been indicated (E1R and E2R). Similarly, the A group has been further subdivided adding the subgroup AR, which considers alteration by beach nourishment. An example of the partitioning of the ASPE code along a coastal tract is reported in Figure 1.

Total length of critical cells (E) is $13 \mathrm{~km}$ (15\% of the total), of which strong erosion affects $4 \mathrm{~km}$. About 51\% of the littoral is accretionary (A) considering also those tracts that have been recently nourished (AR). Stable littorals are $19 \%$, whereas $9 \%$ are precarious. $6 \%$ of the littoral was not validated due to bad data quality.

Similarly to the littoral cells, the shoreline interruptions were mapped as specific cells: the river mouths are sedimentary sources while tidal inlets are sediment traps, as they intercept the sediment transported longshore and store it in the ebb-delta apparatus.

For these special cells an indicator called ASE (Accretion, Stable, Erosion) has been developed. ASE is actually a composite indicator: A, S and E are the three possible states for a river mouth while $S_{e}$ and $S_{d}$ (stable in equilibrium or in disequilibrium) are the only possible states for the deposits of an ebb-tidal delta, according to the potential ebb delta volume vs. tidal prism relationship (FONTOLAN et al., 2007).

\section{Conclusions}

The SICELL method, integrated with the GCV, permits to obtain a rational organization of the coastal data and a practical subdivision of the coastal cells in term of sedimentary budget, thus focusing on the erosional hot spots and conflicts with the urban and tourism planning. The modified version of the Management System contains and catalogues also data on the potential nearshore sedimentary sources/sinks and evaluates their equilibrium and disequilibrium state, in the perspective of the sediment dredging and their use for nourishment. Its application to the coastal area of the Veneto Region, 
Côtes méditerranéennes menacées :

Risques et défis dans le contexte du changement climatique

Italy, demonstrates the efficiency in crossing all the information and defines the priorities in term of intervention and defence strategies.

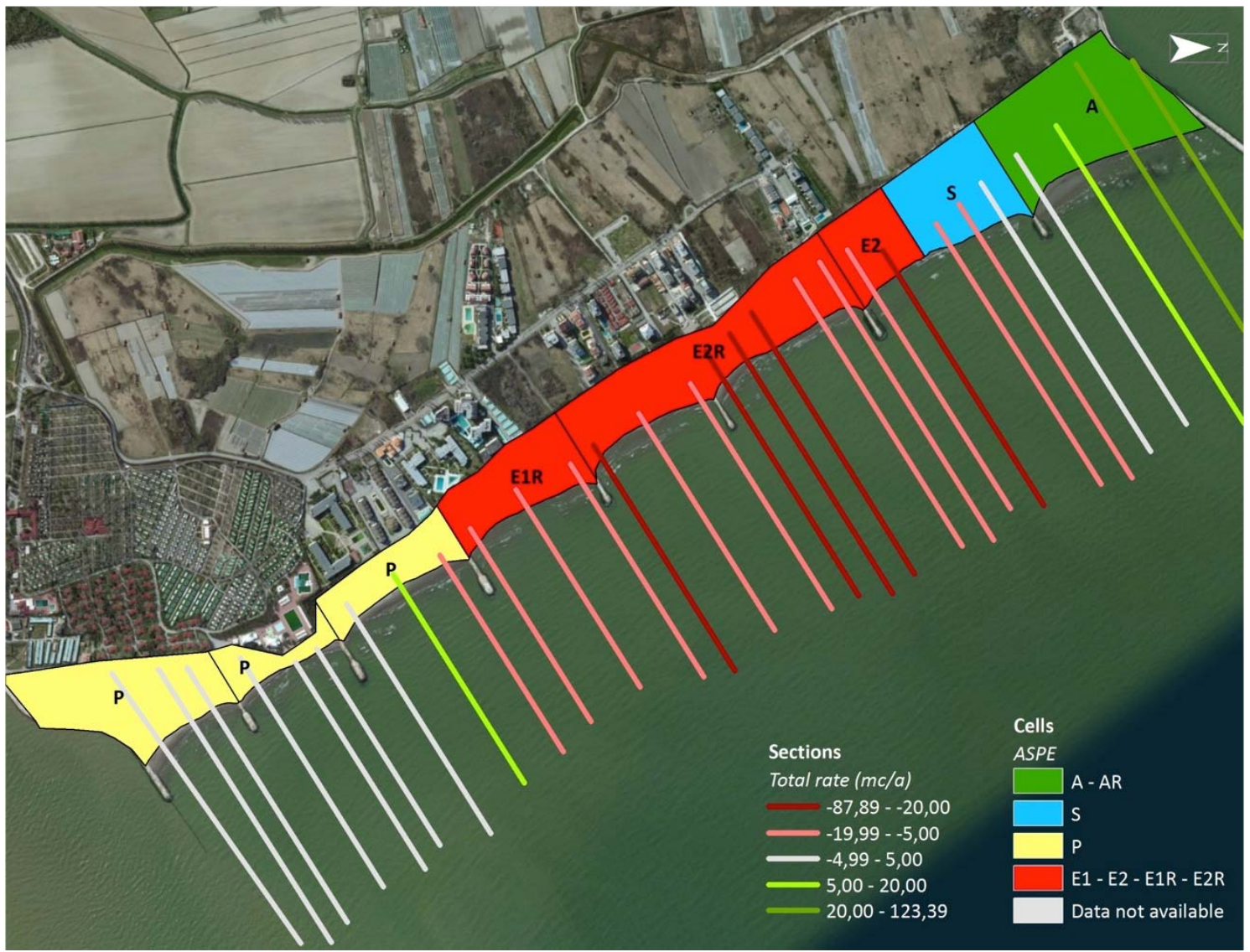

Figure 1. Example of the ASPE code applied to a coastal stretch (Isola Verde). Data on sediment budget (years 2001-2010) refers to the orthogonal bathymetric sections, expresses as cubic meters/a.

\section{References}

FONTOLAN G., PILLON S., DELLI QUADRI F., BEZZI A. (2007). Sediment storage at tidal inlets in northern Adriatic lagoons: ebb-tidal delta morphodynamics, conservation and sand use strategies. Estuarine, Coastal and Shelf Science, Vol. 75, pp 261-277. http://dx.doi.org/10.1016/j.ecss.2007.02.029

KAMINSKY G.M., GELFENBAUM G. (2000). The southwest Washington coastal erosion study: a scientific research project to address management-scale objectives. In: Proceedings of Coastal Society 17th Conference "Coasts at the Millennium". 9-12 July 2000, Portland, Oregon.

REGIONE EMILIA-ROMAGNA (2011). Nuovi strumenti per la gestione dei litorali in Emilia - Romagna, SICELL il sistema gestionale delle celle litoranee. Servizio Difesa del Suolo della Costa e Bonifica, 61 p. 